\title{
64 \\ DESA DAN KOTA DALAM POTRET PENDIDIKAN
}

\author{
Oleh: \\ Azwar Yusran Anas, Agus Wahyudi Riana, \& Nurliana Cipta Apsari
}

Email:

azr29@icloud.com; wahyudiriana@yahoo.com; nurliana.apsari@gmail.com

\begin{abstract}
ABSTRAK
Pendidikan seharusnya sudah menjadi prioritas seluruh masyarakat di Indonesia. Tetapi pendidikan bagi masyarakat miskin bagaikan barang mewah yang tidak bisa mereka beli dan miliki. Salah satu alasan mengapa pendidikan tidak dapat tersentuh oleh masyarakat miskin adalah karena mahalnya biaya pendidikan. Kondisi masyarakat seperti ini ada di desa dan juga di kota. Kondisi pendidikan di kota besar yang memang biaya pendidikannya sudah gratis pun masih memiliki masalah yaitu masalah sulitnya biaya untuk membeli seragam dan juga buku buku sekolah karena pihak sekolah tidak memberikan secara gratis sehingga akhirnya banyak anak anak dikota yang putus sekolah dan akhirnya memilih untuk hidup di jalanan. Sedangkan kondisi pendidikan di desa tidak jauh berbeda dengan di kota persamaan masalahnya yaitu biaya dan juga masalah infrastruktur. Masyarakat desa yang miskin tidak akan bersekolah, kondisi ini diperparah dengan infrastruktur yang tidak lengkap di desa seperti tidak ada SMA di suatu desa sehingga bila masyarakat desa ingin bersekolah ke jenjang SMA maka mereka harus pergi sampai ke kota dan ini membuat masyarakat miskin di desa makin sulit untuk mengakses pendidikan. Sebenarnya pemerintah memiliki kewajiban untuk mengadakan pendidikan yang memadai secara gratis yang di atur dalam Undang Undang Republik Indonesia Nomor 20 Tahun 2003 Tentang Sistem Pendidikan Nasional mengatakan semua warga negara memiliki hak yang sama dalam mendapatkan pendidikan bermutu dan juga semua warga negara berhak mendapat kesempatan meningkatkan pendidikan sepanjang hayat. Maka dengan adanya undang undang yang mengatur hak warga negara dalam mendapatkan pendidikan sudah seharusnya seluruh warga negara Indonesia medapatkan pendidikan sampai ke jenjang yang paling tinggi tanpa harus bergelut dengan permasalahan kemiskinan.
\end{abstract}

Kata Kunci : Pendidikan, kemiskinan di desa dan kota

\section{Pendahuluan}

Menurut Horton dan Hunt, lembaga pendidikan berkaitan dengan fungsi yang nyata (manifes). Mempersiapkan anggota masyarakt untuk mencari nafkah, fungsi laten lembaga sebagai wadah pendidikan, melalui pendidikan di sekolah orang tua melimpahkan tugas dan wewenangnya dalam mendidik anak kepada sekolah.

Sekolah memiliki potensi untuk menanamkan nilai pembangkangan di masyarakat. Katanya pendidikan itu mencerdaskan, tapi kenyataannya pendidikan itu menyesatkan. Lihat saja kualitas pendidikan kita hanya diukur dari ijazah yang kita dapat. Padahal sekarang ini banyak ijazah yang dijual dengan mudahnya dan banyak pula yang membelinya. Hasbullah (2005:1) menyatakan bahwa secara sederhana pendidikan dapat diartikan sebagai usaha manusia untuk membina kepribadiannya sesuai dengan nilai-nilai di dalam masyarakat dan kebudayaan. Pada dasarnya pendidikan adalah laksana eksperimen yang tidak pernah selesai sampai kapan pun, sepanjang ada kehidupan manusia di dunia ini. Dikatakan demikian, karena pendidikan merupakan bagian dari kebudayaan dan 
peradapan manusia yang terus berkembang. Hal ini sejalan dengan pembawaan manusia yang memiliki potensi kreatif dan inovatif dalam segala bidang kehidupannya.

Menurut UU No. 20 tahun 2003 menyatakan pendidikan adalah usaha sadar dan terencana untuk mewujudkan suasana belajar dan proses pembelajaran agar peserta didik secara aktif mengembangkan potensi dirinya untuk memiliki kekuatan spiritual keagamaan, pengendalian diri, kepribadian, kecerdasan, akhlak mulia, serta keterampilan yang diperlukan dirinya, masyarakat, bangsa, dan negara. Pendidikan merupakan fenomena manusia yang fundamental, yang juga mempunyai sifat konstruktif dalam hidup manusia.

Kualitas pendidikan menurut Ace Suryadi dan H.A.R Tilaar (1993:159) merupakan kemampuan lembaga pendidikan dalam mendayagunakan sumber-sumber pendidikan untuk meningkatkan kemampuan belajar seoptimal mungkin.Di dalam konteks pendidikan menurut Umaedi (1999:4), pengertian kualitas atau mutu dalam hal ini mengacu pada proses pendidikan dan hasil pendidikan. Dari konteks "proses" pendidikan yang berkualitas terlibat berbagai input (seperti bahan ajar: kognitif, afektif dan, psikomotorik), metodologi (yang bervariasi sesuai dengan kemampuan guru), sarana sekolah, dukungan administrasi dan sarana prasarana dan sumber daya lainnya serta penciptaan suasana yang kondusif.

Kita ketahui dan rasakan bersama bahwa kondisi pendidikan di Indonesia sampaisaat ini masih belum memberikan hasil yang memuaskan, terlebih jika dihubungkan dengantujuan pendidikan nasional yang tercantum dalam UU No 20 Tahun 2003 bab II pasal 3 yangmenyatakan bahwa "Pendidikan nasional berfungsi mengembangkan dan membentuk watakserta peradaban bangsa yang bermanfaat dalam rangka mencerdaskan kehidupan bangsa,bertujuan untuk berkembangnya potensi peserta didik agar menjadi manusia yang berimandan bertakwa kepada Tuhan Yang Maha Esa, berakhlak mulia, sehat, berilmu, cakap,kreatif, mandiri dan menjadi warga negara yang demokratis serta bertanggungjawab". Pasaltersebut mengisyaratkan bahwa, praktek pendidikan di Indonesia diarahkan kepada upayamengembangkan manusia utuh, manusia yang bukan hanya cerdas dari aspek kecakapanintelektual saja, melainkan juga kepribadian dan keterampilannya, atau dalam istilah penulisinsan yang cerdas otaknya, lembut hatinya dan terampil tangannya.

Pendidikan bermutu dalam pembangunan sebuah bangsa (termasuk di dalamnyapembangunan pada lingkup kabupaten/kota) adalah suatu keniscayaan, melalui pendidikanbermutu dapat dilahirkan sumber daya manusia (SDM) berkualitas dan berdaya saingsebagai salah satu row input proses pembangunan. Tanpa pendidikan yang bermutu tidakmungkin tujuan pembangunan sebuah bangsa dapat terwujud dengan baik. Pendidikanbermutu dan pembangunan berkualitas bagaikan dua sisi mata uang yang tidak dapatdipisahkan satu sama lain.

Dalam konteks bangsa Indonesia, landasan yuridis Undang-Undang Dasar 1945alinea ke empat menyatakan bahwa "....kemudian dari pada itu, untuk membentuk suatupemerintahan negara Indonesia, yang melindungi segenap bangsa, seluruh tumpah darahIndonesia dan untuk memajukan kesejahteraan umum, mencerdaskan kehidupan bangsa...". Merujuk kepada petikan pembukaan UUD 1945 tersebut, jelas bahwa salah satutujuan pembangunan nasional adalah dalam rangka mencerdaskan kehidupan bangsa.Strategi operasional untuk mencapai tujuan tersebut adalah melalui upaya pembangunansektor pendidikan. Dengan demikian, pendidikan merupakan pilar strategis yang tidak bisatergantikan oleh sektor manapun dan sudah menjadi komitmen nasional sejak Negara iniberdiri, sehingga isu pendidikan memiliki kedudukan yang strategis untuk selalu dikaji dandikembangkan. Barizi (2009:129) mengungkapkan bahwa di era globalisasi ini, pendidikanmasih dianggap sebagai kekuatan utama dalam komunitas sosial untuk mengimbangi lajuperkembangan Ilmu Pengetahuan dan Teknologi (IPTEK).

\section{Desa Dan Kota Dalam Potret Pendidikan}

Pendidikan adalah usaha sadar dan terencana bagi para peserta didik untuk menciptakan suasana belajar dan proses pembelajaran agar peserta didik dapat secara aktif mengembangkan potensi dirinya 
untuk memiliki kekuatan spiritual keagamaan, kepribadian,kecerdasan, akhlak mulia serta keterampilan yang dipergunakan untuk dirinya maupun masyrakat disekelilingnya.

pendidikan di kota memang sangat berbeda dibandingkan di desa, dimana kota adalah banyaknya informasi yang ada, dan juga adanya internet yang mendunia saat ini. sedangkan di desa tidak seperti itu bahkan mungkin sebaliknya.Di desa mempunyai komitmen untuk memperolah pendidikan, meskipun mereka jarang memperoleh informasi tentang kejadian yang ada di dunia ini, dan juga mereka berlomba-lomba untuk untuk memeproleh pendidikan yang lebih dari pada yang ada di kota. Banyak orang desa yang pergi merantau ke kota untuk melanjutkan studinya dengan tujuan memperoleh pendidikan yang tinggi. yang pasti mereka akan senang dengan sekolah dikota, karena adanya informasi yang di dapat di dalamnya.

Sangat kontras apabila dicermati dengan kondisi guru di kota yang dipenuhi fasilitas dan kemudahan. Kembali terlintas bagaimana guru di kota mengajar berdasarkan jadwal, dan minus dedikasi serta pengorbanan untuk siswanya, guru kota lebih condong materialistis dan structural. Guru di kota cenderung terikat dengan waktu dan pelit terhadap waktu luang untuk melakukan aktivitas pengembangan siswa. Walaupun tidak keseluruhan berkarakter seperti itu semua, namun umumnya guru di kota cenderung minim rasa pengorban yang benar-benar iklhas.

\section{Pendidikan Di Kota}

Dalam pengertian geografis, kota itu adalah suatu tempat yang penduduknya rapat, rumahrumahnya berkelompok kelompok, dan mata pencaharian penduduknya bukan pertanian. Sementara kota dalam tinjauan geografi adalah suatu bentang budaya yang ditimbulkan oleh unsur-unsur alami dan non alami dengan gejala-gejala pemusatan penduduk yang cukup besar, dengan corak kehidupan yang bersifat heterogen dan materialistis dibandingkan dengan daerah di belakangnya.

Fenomena pendidikan masyarakat perkotaan salah satunya yaitu, masyarakat kelas atas menyekolahkan anaknya di sekolah - sekolah mewah di saat masyarakat golongan ekonomi lemah harus bersusah payah bahkan untuk sekedar menyekolahkan anak mereka di sekolah biasa. Maka, ketimpangan ini dapat memicu kecemburuan yang berpotensi menjadi konflik sosial. Peningkatan kualitas pendidikan yang sudah tercapai akan sia-sia jika gejolak sosial dalam masyarakat akibat ketimpangan karena kemiskinan dan ketidakadilan tidak diredam (Hanakristina,2010). Sekolah yang kualitasnya bagus karena memiliki pengajar yang kompeten, fasilitas lengkap, dan siswa-siswanya cerdas akan semakin bagus. Sedangkan sekolah yang kualitasnya sedang justru sebaliknya. Sekolah yang kualitasnya sedang atau kurang bagus akan menjadi bertambah buruk. Sudah tenaga pengajarnya kurang kompeten, fasilitasnya kurang, siswa-siswanya juga kurang secara akademis.

\section{Pendidikan Di Desa}

Ketidakmampuan desa untuk berhadapan dengan pesatnya kemajuan kota salah satunya diakibatkan oleh kelemahan sistem pendidikan yang ada di desa itu sendiri. Seringkali pengembangan pendidikan yang diterapkan di sekolah-sekolah desa banyak yang tidak disesuaikan terlebih dahulu dengan kebutuhan yang ada di dalam masyarakat. Bahkan yang lebih memprihatinkan dalam penyusunan kurikulum terkadang disamakan dengan pengembangan kurikulum di sekolah-sekolah kota. Hal ini kemudian menyebabkan sekolah-sekolah di pedesaan menjadi tidak mungkin mampu dalam menjawab tantangan serta peluang kerja yang ada di daerahnya sendiri. Akhirnya muncul kecenderungan bila ada seorang anak desa yang terdidik, maka ia akan enggan untuk bekerja di desanya dan selanjutnya lebih memilih pergi untuk mencari pekerjaan yang lebih menjanjikan ke kota.

Mahalnya biaya pendidikan di Indonesia saat ini sudah bukan menjadi masalah baru. Meskipun pemerintah sudah memberikan keringanan melalui beberapa beasiswa bagi siswa yang 
tidak mampu dan berprestasi tetap saja tidak sesuai dengan standar hidup masyarakat Indonesia saat ini. Beberapa fenomena yang saat ni terjadi diantaranya tidak meratanya penyebaran beasiswa yang di berikan pemerintah. Contohnya saja beasiswa tidak mampu tidak tersalurkan seutuhnya pada masyarakat yang memang membutuhkan. Dengan persyaratan yang boleh di bilang tidak terlalu rumit salah satunya adalah melampirkan SKTM (Surat Keterangan Tidak Mampu) dari pemerintah daerah setempat maka calon mahasiswa yang mendaftar bisa dengan mudah mendapatkan beasiswa. Sayangnya saat ini banyak fenomena pemalsuan identitas yang seharusnya calon mahasiswa itu di golongkan pada tingkat mampu menjadi tidak mampu karena sebagian dari mereka berfikir dan enggan mengeluarkan uang yang besar untuk biaya kuliah. Akibat oknum-oknum seperti itulah, masyarakat yang tidak mampu kehilangan kesempatan. Selain itu sebagian mahasiswa di salah satu perguruan tinggi negeri di Bandung juga mengeluhkan tidak mendapatkan fasilitas yang selayaknya. Mahalnya biaya pendidikan di Indonesia kini dirasakan hampir oleh seluruh lapisan masyarakat.

Lalu masalah infrastruktur pendidikan dimana banyak sekali fasilitas-fasilitas sekolah yang sangat buruk dan tidak layak untuk dijadikan sarana penunjang pendidikan. Ribuan gedung sekolah banyak sekali yang ambruk, rusak, dan sudah tidak layak pakai, terutama di daerahdaerah pedesaan. Seharusnya, sebagai sarana pembelajaran, sebuah sekolah harus memiliki gedung dan fasilitas yang baik, agar para siswa nyaman dalam proses pembelajaran. Tidak hanya infrastruktur sekolah yang buruk melainkan juga hinggal ke buku-buku pelajaran siswa yang sudah rusak. Konten dalam sebuah buku pelajaran banyak ditemukan terdapat pornografi didalamnya. Hal ini sangat merusak moral dan etika para siswa yang merupakan tunas bangsa. Seharusnya penerbit buku-buku sekolah menjunjung tinggi etika dalam buku-buku pelajaran yang diterbitkannya. Satu lagi masalah pendidikan yang masih terus diperbincangkan adalah mengenai dana bantuan operasional sekolah (BOS). Dana ini seakan belum efektif bagi semua kalangan, terutama kalangan siswa yang tidak mampu. BOS memang diperuntukkan untuk siswa-siswa tidak mampu namun dana BOS yang cair belum semuanya sampai ke tangan yang berhak. Banyak sekali kasus dana BOS yang disalahgunakan, seperti diambil pihak sekolah dan tidak diberikan kepada siswanya, diambil oleh siswa kalangan mampu, dan yang tidak dipergunakan untuk keperluan bantuan sekolah.

\section{KESIMPULAN}

Dari semua masalah pendidikan di atas, sudah saatnya Indonesia bangkit untuk memperbaiki diri membenahi masalah pendidikan yang ada. Diperlukan peran serta dan pengawasan bersama mulai dari siswa, masyarakat, sampai ke pemerintah. Bagaimanapun juga, pendidikan adalah salah satu aset penting perkembangan dan kemajuan bangsa. Jika para tunas muda bisa sampai kehilangan dan tidak merasakan pendidikan yang baik, Indonesia ke depan juga tidak dapat diharapkan masa depannya karena tidak ada generasi penerus yang dapat membawa Indonesia ke puncak kejayaan. Oleh karena itu, berkaca dari masalah-masalah di atas, harapannya agar segera dapat diatasi setidaknya mulai dari hal kecil dulu, seperti menanamkan pentingnya pendidikan pada semua kalangan.

\section{DAFTAR PUSTAKA}

Ali.. Guru Dalam Proses Belajar Mengajar.Bandung: Sinar Baru, 1984

Dinas Pendidikan Propinsi Jawa Barat. Pedoman Implementasi Manajemen Berbasis Sekolah di Jawa Barat. Bandung, 2002

Depdikbud.. Kamus Besar Bahasa Indonesia, Jakarta : Balai Pustaka, 1996

Fungsi dan Prinsip Model Make-A Match (Online)

(http://Tarmizi.Wordpress.com/2008/12/03/pembelajaran-kooperatif-

(http://herdy07.wordpress.com/2009/04/29) (diakses 05 Mei 2014)Dimyati, dkk, 2006, 
Belajar dan Pembelajaran, Jakarta: Rineka Cipta.Gagne. (The Conditions of Learning,1977). Pengertian Belajar (http://belajarpsikologi.com/pengertian-belajarmenurut ahli/2 (diaksesdiakses 05 Mei 2014)Hamalik. (1994:116).

Peran Guru dan Siswa dalam Model Make-A Match, Ali Imran, Pembinaan Guru di Indonesia. Jakarta : Pustaka Jaya, 1995. 